\title{
The Development of A Handout on Eubacteria Concept for High School
}

\author{
Aulia Ajizah, Khairunnida Rahma \\ Biology Education Department, Faculty of Teacher Training and Education \\ Universitas Lambung Mangkurat \\ Banjarmasin, Indonesia \\ aulia ajizah@yahoo.com
}

\begin{abstract}
In regard to Eubacteria, basic competencies in Biology for tenth grade students include the ability to provide data on characters and roles of bacteria in life. Amongst the disadvantages of bacteria as exemplified by Escherichia coli is as the agent of human diseases. One way to overcome bacterial infection is by using natural products. The present study was focused on the development of a handout for providing information based on existing data on the sensitivity of Escherichia coli to gandaria (Bouea macrophylla) seed. This study applied a research and development approach as proposed by Borg \& Gall (2006) up to product revision step. The results showed that the overall validity of the handout was very high $(82,28 \%)$, including the content $(81.25 \%)$, presentation $(80 \%)$, and language $(85,58 \%)$ aspects. For the aspect of the readability, students suggested that the handout was highly readable $(83 \%)$.
\end{abstract}

Keywords-Bouea Macrophylla, Development of A Handout, Eubacteria, Sensitivity Of Escherichia Coli

\section{INTRODUCTION}

Based on the 2013 curriculum syllabus revision in 2016 issued by the Indonesian Ministry of Education and Culture [1], Biology has 11 basic competencies that must be mastered by students in class $\mathrm{X}$ of SMA/MA (junior high school) within 2 (two) semesters. One material that must be mastered by the students in class $\mathrm{X}$ in the first semester is about archaebacteria and eubacteria. In the curriculum, students are required to learn about archaebacteria and eubacteria by identifying their structure, way of life, reproduction, and role in life. Interesting topic to be studied is the role of bacteria in life.

The bacteria that exist in nature have their respective roles, either beneficial or detrimental role. For example, beneficial role of Escherichia coli, which is the normal flora in the human gut, is to help digestive process. However, these bacteria can also contribute harm if the amount is above the threshold. Excessive Escherichia coli bacteria can cause infection/diarrhea disorders [2]. There is much of the information about human efforts in tackling the dangers of harmful bacteria using natural materials. However, there is not much information on the matter in the form of learning support materials like handouts, especially for the students of class X at SMA for the first semester derived from research. Thus, it is necessary to make additional information on natural materials (particularly from plants typical of a region) that have the potential to inhibit the growth or even to kill bacteria that cause disruption. However, this growth inhibitory potential depends on the sensitivity of bacteria to natural materials presented to them, so it is important to notice the sensitivity of bacteria or bacterial sensitivity to the natural material.

One of typical plants of South Kalimantan is Ramania ( 'Gandaria' in Indonesian language). Ramania is a bog plant that is still little known beneficial as a medicinal plant. Ramania (Bouea macrophylla) is one type of Anacardiaceae family, originating from the islands of Indonesia and Malaysia [3]. According to [4], based on the results of screening chemical constituents contained in the methanol extract of the seeds of Ramania (Bouea macrophylla), Ramania is a class of flavonoids and triterpenoids/steroids. With the presence of both secondary metabolites, Ramania seed is thought to have the ability to inhibit bacterial growth. It needs to be proven scientifically. Therefore, the potential for inhibition of bacterial growth is evidenced by exposing it to bacteria in vitro test. This study aimed to produce teaching materials in the form of handout containing additional information about sensitivity of Escherichia coli that is tested using infuse Ramania seed (Bouea macrophylla) for the material of eubacteria. The handout is quick learning materials, sourced from some of the literature relevant to the basic competencies and subject matter being taught to students [5]. It is expected that generated handout will be able to add information about the characteristics of the bacteria studied by students, especially Escherichia coli. The handout will be distributed to students through the validation phase. According to [6], validity is a measure that states the level of validity of an instrument and an instrument is considered valid if the instrument is able to measure what should be measured.

\section{METHOD}

This study was the R\&D research (Research and Development). R\&D research aims to produce and test the effectiveness of products [7] through development process. The development model used was a modification of the Borg and Gall, which aimed to get the procedure custom development.

This study procedure was adapted the development model of Borg and Gall. The research steps included potential and 
problems, information collection, the initial product design, design validation, and revision of the design.

(1). Potensial and Problems. Tuhepaly's research results [7] on the phytochemical screening of Ramania seed or Gandaria showed that there is the content of secondary metabolites such as flavonoids and triterpenoids/steroids. Both of these contents are thought to have antibacterial activity that is able to inhibit the growth of bacteria. Therefore, research on the potential of this Ramania seed is against a growth of bacterium Escherichia coli in the form of infusion. Meanwhile, in the tenth grade high school in the first semester, there is a basic competence of the archaebacteria and eubacteria that requires students to get to know the characteristics of bacteria and some examples of bacteria that play a role in human life. One is the Escherichia coli bacterium that can cause diseases of the digestive tract, especially diarrhea. Thus, additional information regarding Escherichia coli needs to be delivered to students.

The question is how to convey the information to the students in learning in order to be a material enrichment or additional information about concepts of eubacteria. One effective way to deliver information according to [8] is to provide teaching materials. Therefore, information about the sensitivity of Escherichia coli bacteria is used as a material for the enrichment of this concept, which is designed in the form of handout. In addition, the handout made is not only material enrichment of Eubacteria but also the potential of using the local vegetation typical of Borneo.

(2). Information Collection. Collecting information was done through a research on the sensitivity of Escherichia coli to infuse seed Ramania (Bouea macrophylla). The results of this study were designed in the form of a simple form of handout as additional information about the concept of Eubacteria. In addition, the researchers examined references and other learning resources related to this concept, in particular about Escherichia coli bacterium.

Research on Escherichia coli's bacterial sensitivity refers to the testing methods of anti-microbe by Kirby-Bauer. These antimicrobial material test uses disc diffusion method (Disc Diffusion Method). The steps of test of antimicrobial material are as follows: (a) making infuse Ramania seed which refers to the technique of making infuse simplicia according to Pharmacopoeia Indonesia, (b) making a bacterial suspension test in accordance with the standards of Mc. Farland 0.5, (c) testing the minimal inhibitory concentration (MIC) by the concentration series of $50 \%, 25 \%, 12.5 \%, 6.25 \%$ and $3.125 \%$. Then, the basis concentration for testing of antibacterial by the MIC test is determined, (d) testing the antibacterial ability of Ramania seed with disc diffusion method by taking the following procedure:

i. Infuse concentration of $40 \%, 45 \%, 50 \%, 55 \%$, and $60 \%$ $(\mathrm{MIC}=50 \%)$ was made.

ii. Mueller-Hinton seaweed medium was made and put into a test tube screw cap, and then sterilized.

iii. After it is sterile, let it remain in a liquid state and the medium temperature around $40{ }^{\circ} \mathrm{C}$ and inoculating $200 \mu \mathrm{l}$ bacterial suspensions. Then, it was made into homogenous state.

iv. The mixture was poured into a sterile Petri container, and it was left solid.

v. Meanwhile, the paper discs were soaked in sterile cups for each concentration treatment.

vi. Once solidified, the medium was divided into 7 sectors; 5 sectors for 5 infuse concentrations of test, one sector to distilled water as a negative control, and one sector for amoxicillin antibiotics as a positive control.

vii. The paper discs of each concentration treatment were put to each sector.

viii. The entire treatment was incubated in an incubator at $37^{\circ}$ C for 24-48 hours.

ix. After incubation, the width of the diameter of Escherichia coli bacterial growth inhibitory was measured and formed as a clear zone around the paper disk.

$\mathrm{x}$. The data were processed and analyzed.

(2). The Initial Product Design. Handout framework by the Ministry of Education [9] contains the title and supporting information only. Therefore, the handout is one of the teaching materials that are easily made and understood by users.

TABLE I. MODIFIED HANDOUT FRAMEWORK (2008)

\begin{tabular}{|c|l|l|}
\hline No & \multicolumn{1}{|c|}{ Component } & \multicolumn{1}{c|}{ Description } \\
\hline 1 & Title & $\begin{array}{l}\text { a. Cover } \\
\text { b.Preface } \\
\text { c. Table of contents }\end{array}$ \\
\hline 2 & $\begin{array}{l}\text { Standard competencies } \\
\text { and basic competencies }\end{array}$ & $\begin{array}{l}\text { Standard competencies of Biology } \\
\text { for grade X of high school } \\
\text { Basic competencies 3 }\end{array}$ \\
\hline 3 & Main material & $\begin{array}{l}\text { Learning materials about the roles } \\
\text { of bacteria in life }\end{array}$ \\
\hline 4 & Supporting information & $\begin{array}{l}\text { a. Supporting information: } \\
\text { Introduction (Background, roles } \\
\text { of bacteria in life, Mitigation } \\
\text { efforts to handle hazard of } \\
\text { bacteria, general information } \\
\text { about Ramania, secondary } \\
\text { metabolites on Ramania seed as } \\
\text { antibacterial agents) }\end{array}$ \\
& & $\begin{array}{l}\text { b. Research methods } \\
\text { a.Potency of Ramania seed } \\
\text { infusion as Escherichia coli } \\
\text { antibacterial agent for in vitro } \\
\text { b. Conclusions } \\
\text { c. Exercises } \\
\text { d.Glossaries } \\
\text { e. Bibliographies }\end{array}$ \\
\hline 5 & Material content & \\
& &
\end{tabular}

The steps to create teaching materials in the form of handout adapted from [5] are as follows:

(a). Determining the appropriate handout title to the results of the research of sensitivity of Escherichia coli to antibacterial material of Ramania seed (Bouea macrophylla)

(b).Collecting reference material as the supporting material handouts. Reference used is a current and relevant reference to the subject matter. 
(c). Designing a handout outline

(d).Making handouts with regard understandable writing techniques for high school students

(e). Placing images and text to be proportional and interesting

(f). Evaluating the design and content of the handout

(3). Design Validation. The handout was validated by two experts as supervisor 1 and supervisor 2 . The readability validation was performed by students of class $\mathrm{X}$ in SMA 7 Banjarmasin. The two experts did the steps of validation of contents (material) as follows:

(a).Giving the assessment instruments that include feasibility aspects of content, presentation feasibility aspects, and aspects of language assessment

(b). Checking the results of the charging instrument by experts

(c). Cultivating a score as a percentage (\%) by using the formula:

$$
\mathrm{Pi}=\frac{\mathrm{Xi}}{\mathrm{Yi}} \times 100 \%
$$

Where $\mathrm{Pi}=$ the percentage of assessment for the i-th aspects; $\mathrm{Xi}=$ number of assessment that validator answers to for the $\mathrm{i}$-th aspects, and $\mathrm{Yi}=$ the number of maximum value to aspects for the $\mathrm{i}$-th

(d). Comparing the scores obtained with the validity criteria instructional materials

Readability test was conducted toward five students of class $\mathrm{X}$ in SMA 7 Banjarmasin as follows:

(a). The handout was distributed to five students of class $X$ in SMA 7 Banjarmasin.

(b). An assessment instrument that includes aspects of language assessment, the appeal of the students to read, the level of ease the passage, as well as suggestions was distributed

(c). The results of the charging instrument by students were checked and the final value was calculated using the formula:

$$
\mathrm{P}=\frac{\text { Obtained Scores }}{\text { Maximum Scores }} \times 100 \%
$$

(d). The scores obtained with readability criteria of teaching materials were compared.

(4). Design Revision. After the test of validity by expert and readability test by students, the handout design was revised based on the validation and test results. Design improvements were made with reference to the criticisms and suggestions given by the validators and the students.

\section{RESUlt AND DisCUSSIONS}

\section{A. The Developed Material}

The material developed in this study was the result of study on the sensitivity of Escherichia coli to the seeds of Ramania (Bouea macrophylla), which was designed to be a handout as one of instructional materials for additional information regarding the teaching materials of eubacteria. The results of this study was as a means to exploit local potential as a basis for developing teaching materials in schools.

A need analysis (potential and problem) was done by assessing the Biology syllabus for class X of SMA / MA in first semester corresponding to the study conducted. Basic competence was developed into a handout with basic competencies 3.5 , namely identifying the structure, way of life, reproduction, and the role of bacteria in the material life in the role of bacteria in life. Subject matters in biology about the role of bacteria in life are: (1) the role of beneficial bacteria, (2) the role of harmful bacteria, and (3) the impact mitigation.

\section{B. Collected Information}

Information through research of infuse seed Ramania (Bouea macrophylla) testing against Escherichia coli bacteria in vitro was supported with the other references. Testing was conducted by experiments using total plate count method. Of Minimal Inhibitory Concentration (MIC)

Determination of minimal inhibitory concentration used the series of dilution method with a concentration that is from $50 \%, 25 \%, 12.5 \%, 6.25 \%$, up to $3.125 \%$. After incubation of 24 hours at a temperature of $37^{\circ} \mathrm{C}$, the results is shown in Table II.

TABLE II. MIC TEST RESUlt OF RAMANIA SEED INFUSION

\begin{tabular}{|c|c|}
\hline Concentration & Bacteria Colony \\
\hline $50 \%$ & 0 colony \\
$25 \%$ & 32 colonies \\
$12,5 \%$ & TNTC \\
$6,25 \%$ & TNTC \\
$3,125 \%$ & TNTC \\
\hline
\end{tabular}

Information: TNTC (Too Numerous To Count)

\section{Sensitivity Test of Escherichia coli}

The sensitivity test of Escherichia coli refers to the antibacterial testing according to the Kirby-Bauer method. The results show the wide diameter of growth inhibition of Escherichia coli. 
TABLE III. THE INHIBITION DIAMETER WIDTH THAT FORMED ON AGAR

\begin{tabular}{|c|c|c|c|c|c|c|}
\hline \multirow{2}{*}{ No } & \multirow{2}{*}{ Conc. } & \multicolumn{3}{|c|}{ Inhibition Diameter Width (mm) } & \multirow{2}{*}{$\begin{array}{c}\text { Average } \\
\text { (mm) }\end{array}$} \\
\cline { 3 - 6 } & $\mathbf{1}$ & $\mathbf{2}$ & $\mathbf{3}$ & $\mathbf{4}$ & 6,00 \\
\hline & $\begin{array}{c}\text { Negative } \\
\text { control }\end{array}$ & 6,00 & 6,00 & 6,00 & 6,00 & \\
3 & $40 \%$ & 9,08 & 14,03 & 9,03 & 8,10 & 10,06 \\
4 & $45 \%$ & 12,08 & 16,03 & 14,04 & 9,58 & 12,93 \\
5 & $50 \%$ & 16,03 & 16,08 & 10,08 & 15,03 & 14,30 \\
6 & $55 \%$ & 18,03 & 16,04 & 14,07 & 11,09 & 14,80 \\
7 & $60 \%$ & 23,02 & 17,06 & 19,01 & 21,01 & 20,02 \\
& $\begin{array}{c}\text { Positive } \\
\text { control }\end{array}$ & 24,90 & 26,05 & 23,00 & 22,07 & 24,01 \\
\hline
\end{tabular}

*Inhibition zone diameter measurements including disc diameter 6 $\mathrm{mm}$
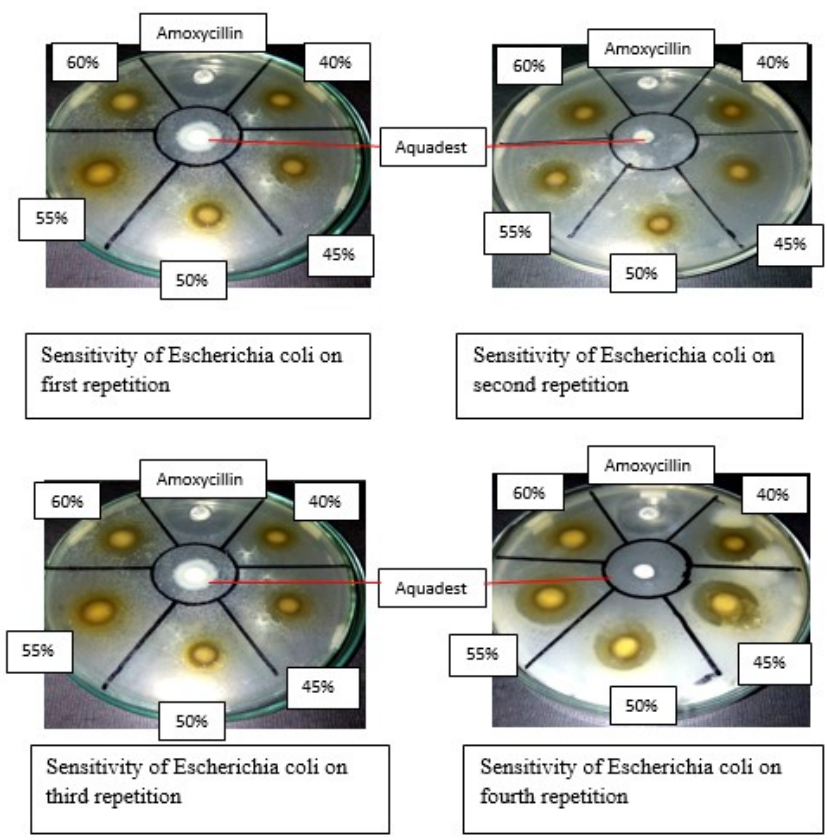

Fig. 1. Sensitifity of Escherichia coli on each repetition

The sensitivity of bacteria and inhibitory infuse Ramania seeds from each treatment were also determined by reference to the Clinical and Laboratory Standards Institute in 2012 (Table IV).

The sensitivity of Escherichia coli to infuse fruit seeds of Ramania is possible because of its active compound content. Chemical constituents contained in the methanol extract of the seeds of Ramania (Bouea macrophylla) are a class of flavonoids and triterpenoids/steroids. Flavonoids and triterpenoids/steroids are one of secondary metabolites capable of acting as an antibacterial. Sensitivity and strength of power resistor (Table IV) has potential as an antibacterial material. The presence of antibacterial compounds could be developed by human being as an attempt to overcome the dangers of bacteria.
TABLE IV. MIC TEST RESUlt OF RAMANIA SEED INFUSION

\begin{tabular}{|c|c|c|c|c|}
\hline No & Concentration & $\begin{array}{c}\text { Average } \\
\text { (mm) }\end{array}$ & Sensitivity & Strength \\
\hline 1 & Negative & 6,00 & Resistant & Moderate \\
\hline 2 & $40 \%$ & 10,06 & Resistant & Moderate \\
\hline 3 & $45 \%$ & 12,93 & Intermediate & Strong \\
\hline 4 & $50 \%$ & 14,30 & Intermediate & Strong \\
\hline 5 & $55 \%$ & 14,80 & Intermediate & Strong \\
\hline 6 & $60 \%$ & 20,02 & Intermediate & Strong \\
\hline 7 & Positive & 24,01 & Sensitive & Very strong \\
\hline
\end{tabular}

\section{Initial Product Design}

The handout framework was developed by designing handout as review of references, namely:

- COVER PAGE

- FOREWORD

- TABLE OF CONTENTS

- INSTRUCTIONS LEARN

- CORE COMPETENCE

- BASIC COMPETENCIES

- INDICATOR

- LEARNING MATERIALS

- CHAPTER I INTRODUCTION

1.1 Background,

1.2 Roles Of Bacteria In Life

1.3 Mitigation Efforts To Handle Hazard Of Bacteria

1.4 General Information About Ramania

1.5 Secondary metabolites on Ramania seed as antibacterial agents

1.6 Research Methods

1.6.1 Research Equipments and Materials

1.6.2 Sampling

1.6.3 Research Procedure

CHAPTER II Escherichia coli SENSITIVITY TOWARD

RAMANIA SEED INFUSION (Bouea macrophylla) FOR IN VITRO

CHAPTER III CONCLUSION

EXERCISES

BIBLIOGRAPHY

GLOSSARY

\section{E. Design Validation}

Teaching materials in the form of handout developed become enrichment materials for the tenth grade at first semester on Biology as a material on role of bacteria in life. Two experts (supervisor 1 and 2) validated this handout. The results of the validation tests conducted by 2 experts are shown in Table V. 
TABLE V. VALIDATION RESULT OF CONTENT ASPECTS

\begin{tabular}{|c|c|c|c|}
\hline Indicator & Description & $\begin{array}{c}\text { Validator } \\
1\end{array}$ & $\begin{array}{c}\text { Validator } \\
2\end{array}$ \\
\hline $\begin{array}{l}\text { A. Suitability of } \\
\text { materials } \\
\text { with standard } \\
\text { competencies } \\
\text { and basic } \\
\text { competencies }\end{array}$ & $\begin{array}{l}\text { 1. The completeness of } \\
\text { material } \\
\text { 2. The depth of material }\end{array}$ & $\begin{array}{l}3 \\
3\end{array}$ & $\begin{array}{l}4 \\
3\end{array}$ \\
\hline $\begin{array}{l}\text { B. Accuracy of } \\
\text { Material }\end{array}$ & $\begin{array}{l}\text { 3. Acuracy of concepts and } \\
\text { definition } \\
\text { 4. The accuracy of the } \\
\text { facts and data } \\
\text { 5. The accuracy Example } \\
\text { 6. The accuracy of } \\
\text { exercises } \\
\text { 7. The accuracy of } \\
\text { drawings, diagrams } \\
\text { and illustrations } \\
\text { 8. The accuracy of the } \\
\text { reference library }\end{array}$ & $\begin{array}{l}3 \\
4 \\
3 \\
3 \\
4\end{array}$ & $\begin{array}{l}3 \\
4 \\
3 \\
3 \\
4\end{array}$ \\
\hline $\begin{array}{l}\text { C. Supporting } \\
\text { learning } \\
\text { material }\end{array}$ & $\begin{array}{l}\text { 9. Reasoning } \\
\text { 10. Lingkage } \\
\text { 11. Communication } \\
\text { 12. Application } \\
\text { 13. The attractiveness of } \\
\text { the materials } \\
\text { 14. Encourage to seek } \\
\text { further information } \\
\text { 15. Coompliance with the } \\
\text { materials science } \\
\text { development } \\
\text { 16. Drawing, diagrams and } \\
\text { actual illustrations } \\
\text { 17. Using the examples } \\
\text { cases in and outside } \\
\text { Indonesia }\end{array}$ & $\begin{array}{l}3 \\
3 \\
4 \\
2 \\
3 \\
4 \\
3 \\
4 \\
3\end{array}$ & $\begin{array}{l}3 \\
3 \\
3 \\
4 \\
3 \\
3 \\
3 \\
3 \\
3\end{array}$ \\
\hline $\begin{array}{l}\text { D. Recency of } \\
\text { material }\end{array}$ & 18. Recency of the library & 3 & 3 \\
\hline \multicolumn{2}{|c|}{ Total Scores (Maximum 72 points) } & 58 & 59 \\
\hline \multicolumn{2}{|l|}{ Validaty Score } & \multicolumn{2}{|c|}{$81,25 \%$} \\
\hline
\end{tabular}

TABLE VI. VALIDATION RESULT OF PRESENTATION FEASIBILITY ASPECTS

\begin{tabular}{|c|c|c|c|}
\hline Indicator & Description & $\begin{array}{c}\text { Validator } \\
1\end{array}$ & $\begin{array}{c}\text { Validator } \\
2 \\
\end{array}$ \\
\hline $\begin{array}{l}\text { A.Presentation } \\
\text { technique }\end{array}$ & $\begin{array}{l}\text { 1. Consistency systematic } \\
\text { grain in learning } \\
\text { activities } \\
\text { 2. The coherence of } \\
\text { presentation }\end{array}$ & 3 & 3 \\
\hline $\begin{array}{l}\text { B. Accuracy of } \\
\text { Material }\end{array}$ & $\begin{array}{l}\text { 3. Introduction } \\
\text { 4. Table of contents } \\
\text { 5. Summary } \\
\text { 6. Bibliography }\end{array}$ & $\begin{array}{l}3 \\
4 \\
2 \\
3\end{array}$ & $\begin{array}{l}3 \\
4 \\
3 \\
4 \\
\end{array}$ \\
\hline $\begin{array}{l}\text { C. Learning } \\
\text { presentation }\end{array}$ & $\begin{array}{l}\text { 7. Student engagement } \\
\text { 8. The introduction } \\
\text { 9. Content } \\
\text { 10. Closing }\end{array}$ & $\begin{array}{l}2 \\
3 \\
4 \\
3\end{array}$ & $\begin{array}{l}2 \\
3 \\
4 \\
3\end{array}$ \\
\hline \multicolumn{2}{|c|}{ Total Scores (Maximum 40 points) } & 31 & 33 \\
\hline \multicolumn{2}{|l|}{ Validaty Score } & \multicolumn{2}{|c|}{$80 \%$} \\
\hline
\end{tabular}

TABLE VII. VALIDATION RESULT OF LANGUAGE ASPECTS

\begin{tabular}{|c|c|c|c|}
\hline \multicolumn{1}{|c|}{ Indicator } & Description & $\begin{array}{c}\text { Validator } \\
\mathbf{1}\end{array}$ & $\begin{array}{c}\text { Validator } \\
\mathbf{2}\end{array}$ \\
\hline A. Straightforward & $\begin{array}{c}\text { 1. Accuracy of sentence } \\
\text { structure }\end{array}$ & 3 & 4 \\
\hline
\end{tabular}

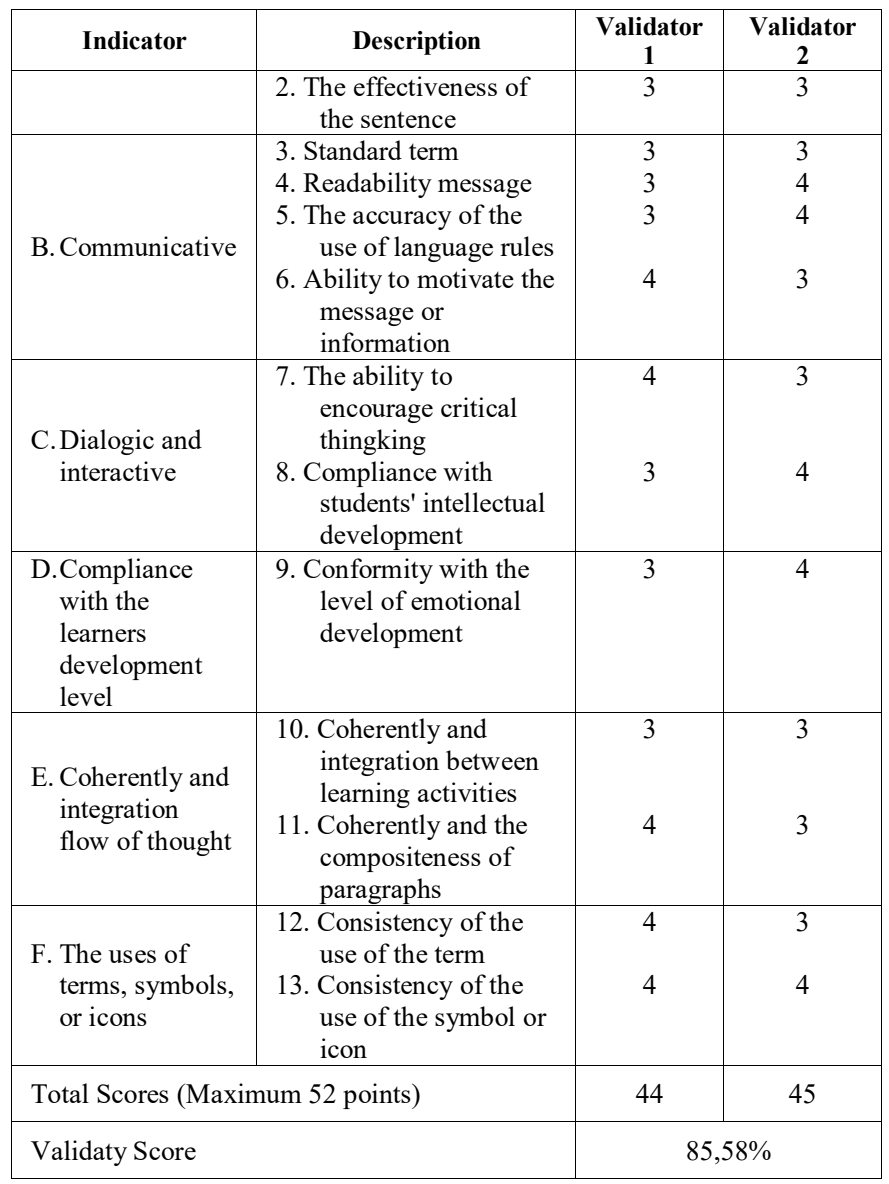

The criteria used were based on Pratama (2014) with a very valid statement ( 79,78 to 100$)$, valid $(59,52$ to 79,77$)$, less valid $(39,26$ to 59,51$)$ and invalid $(19,00$ to 39,25$)$. Based on these criteria, the handout made in the study on the feasibility aspect of the content, presentation feasibility aspects, and aspects of language assessment was categorized very valid.

\section{TABLE VIII. READABILITY TEST RESULT}

\begin{tabular}{|c|c|c|c|c|c|}
\hline \multirow{2}{*}{ No. } & \multirow{2}{*}{ Aspect } & \multicolumn{4}{|c|}{ Score } \\
\hline & & 1 & 2 & 3 & 4 \\
\hline 1. & $\begin{array}{l}\text { Design of cover page already attractive and describe } \\
\text { the content. }\end{array}$ & 0 & 0 & 5 & 0 \\
\hline 2. & $\begin{array}{l}\text { Pictures inside the handout attractive and } \\
\text { appropriate with the topic. }\end{array}$ & 0 & 0 & 5 & 0 \\
\hline 3. & Pictures are clear and not blurry. & 0 & 0 & 3 & 2 \\
\hline 4. & $\begin{array}{l}\text { Handout use clear font, combination of font, color, } \\
\text { and picture are match. }\end{array}$ & 0 & 0 & 2 & 3 \\
\hline 5. & Sentences in handout are easy to understand. & 0 & 1 & 3 & 1 \\
\hline 6. & $\begin{array}{l}\text { Pictures are clear and easy to understand the } \\
\text { meaning. }\end{array}$ & 0 & 0 & 1 & 4 \\
\hline 7. & Terms inside the handout are easy to understand. & 0 & 0 & 5 & 0 \\
\hline 8. & $\begin{array}{l}\text { Materials that served inside the handout are in } \\
\text { order. }\end{array}$ & 0 & 0 & 2 & 3 \\
\hline 9. & There is no ambiguous words. & 0 & 0 & 4 & 1 \\
\hline 10. & Enrichment materials are easy to understand. & 0 & 0 & 3 & 2 \\
\hline & Total Score & 0 & 1 & 33 & 16 \\
\hline & Readibibility Score & \multicolumn{4}{|c|}{$82,50 \%$} \\
\hline
\end{tabular}


Teaching materials in the form of handout were created through the process of testing the readability. Readability tests involved five students of class X in SMA 7 Banjarmasin. The test results are presented in Table VIII. The readability test was performed to determine students' opinion, which later used as the teaching materials developed.

Readability score refers to [10] with the modification of the scoring criteria as follows: $0 \%-24.9 \%$ (very readable), $25 \%$ $49.9 \%$ (very illegible), $50 \%-74.9 \%$ (illegible), and $75 \%-100 \%$ (very readable). Based on this, the teaching materials in the form of handout that made have been classified as very legible.

\section{F. Imprived Design}

Once validated, the handout was made through the process of revision based on the suggestions of the validators. The suggestions given by the validators on the first validation is an input in the revision process (Table IX).

TABLE IX. SUGGESTION FROM VALIDATOR 1 AND VALIDATOR 2

\begin{tabular}{|l|}
\hline \multicolumn{1}{|c|}{ Validator 1 } \\
\hline 1. There are no case examples. \\
2. Create biology evaluation questions base on the research result. \\
3. Follow handout presentation format. \\
4. Introduction should not be too much to discuss about the curriculum \\
but focuses on bacteria and antibacterial agents. \\
5. Make a short procedure but more communicative. \\
\hline \multicolumn{1}{|c|}{ Validator 2} \\
\hline 1. Add evaluation questions that suitable with learning purposes and \\
basic competencies. \\
2. Connect the content with material/concept that suitable with basic \\
competencies. \\
3. Make more communicative and could motivate the students. \\
4. Make students to use their critical thinking skills. \\
5. Make students to be more motivated to find information. \\
6. Make students to be more involved. \\
\hline
\end{tabular}

The students who did readability test also gave feedback and input. The suggestions given by the five students on the test of readability were as input in the revision process (Table $10)$.

TABLE X. SUGGESTION FROM STUDENTS

\begin{tabular}{|l|}
\hline \multicolumn{1}{|c|}{ Suggesstion } \\
\hline 1. Cover page's color is opaque. It should be replaced with a more \\
attractive color. \\
2. The handout lacks of figure. Addmore figures along with an \\
explanation. \\
3. Enhance image quality. \\
4. Color photos / pictures a little murky and unattractive. \\
\hline
\end{tabular}

\section{CONCLUSION}

The product in the form of handout about Eubacteria materials based on research about sensitivity of Escherichia coli to infuse Ramania fruit seeds can be summarized as follows: (1) The growth of Escherichia coli significantly $(\mathrm{P}<0.05)$ could be hampered by infusion of Ramania seed infusion (Bouea macrophylla); 2) The handout with the topic of the sensitivity of Escherichia coli toward Ramania seed infusion (Bouea macrophylla) was regarded very valid $(81,25 \%)$ on the feasibility aspect of the contents, very valid $(80 \%)$ on the feasibility aspect of presentation, and language aspects was also regarded very valid $(85,58 \%)$, as well as expressed by students as very readable handout $(82,50 \%)$.

\section{REFERENCES}

[1] Kementrian Pendidikan dan Kebudayaan Republik Indonesia, "Silabus Mata Pelajaran Biologi Sekolah Menengah Atas/ Madrasah Aliyah (SMA/MA)", Jakarta, 2016, unpublished

[2] Andayasari Anorital \& Lelly, "Kajian epidemiologi penyakit infeksi saluran pencernaan yang disebabkan oleh amuba di Indonesia", Media Litbang Kesehatan, Vol. 21, No. 1, 2011.

[3] Landy A. Ch. Lolaen,"Uji Aktivitas Antioksidan Kandungan Fitokimia Jus Buah Gandaria (Boueamacrophylla griffith)", Program Studi Farmasi Fakultas MIPA UNSRAT, Manado, 2013.

[4] Ida F. Tuhepaly, "Uji Praskrinning Aktivitas Antikanker Biji Gandaria (Boueamacrophylla griffith) dengan Metode Brine Shrimp Lethality Test (Bst) (Ekstrak N-Heksanadan Metanol), Universitas Muhammadiyah Malang, Malang, 2012.

[5] Andi Prastowo, Panduan Kreatif Membuat Bahan Ajar Inovatif, Jogjakarta: Diva Press, 2015.

[6] Hardiansyah, Evaluasi Pendidikan Biologi, Banjarmasin: Program Studi Pendidikan Biologi, 2011.

[7] Sugiyono, Metode Penelitian Kuantitatif, Kualitatif, dan R\&D, Bandung: Alfabeta, 2014.

[8] M. N. Darkuni, Pengembangan Bahan Ajar Bidang Studi Biologi, Malang: UMN, 2010.

[9] Depertemen Pendidikan Nasional, Panduan Pengembangan Bahan Ajar, Jakarta: Direktorat Pembinaan Sekolah Menengah Atas, 2008.

[10] Abdul Rohmad, "Pengembangan Lembar Kerja Siswa (LKS) berbasis eksplorasi, elaborasi, dan konfirmasi (EEK) serta kebencanaan sebagai bahan ajar mata pelajaran Geografi SMA/MA di Kabupaten Rembang”, Edu Geography, Vol. 2(2), 2013. 